\title{
Using Reflective Processes to Promote Attention to Diversity in SCHOOLS: A StUdy OF Practice in ChIIL
}

\author{
El Uso de Procesos Reflexivos en las Escuelas para \\ Fomentar la Atención a la Diversidad de Alumnos y Alumnas: \\ Dos Estudios de Caso en Chile
}

Ana Luisa López

PhD student, University of Manchester

analuisalz@yahoo.es

Received: May 7, 2008. Accepted: September 5, 2008

\begin{abstract}
Over the last decade or so, many writers have argued that inclusive practices are more likely to be developed when school communities are involved in collaborative processes of inquiry, reflection and action in order to learn how to respond to learners' diversity. The research was camied out in two schools (with names changed for ethical reasons) with different characteristics: Innovacion School, in Santiago, is one of the pioneer schools in the country in integrating disabled students, whilst Loncomahuida School is located in one of the most isolated rural areas of Chile and responds to a high population of students of a Mapuche ethnia.

Guided by literature on action research, the study made use of an inclusive action research model that guided the process in both schools. This model emphasises the need to concentrate efforts on the promotion of reflective practitioners, as well as reflective communities. It also involves a team of co-researchers, formed by volunteers from the schools, planned to internalize and coordinate the process in each institution.

The research set out to throw light on how educational communities in Chile can develop sustainable strategies for encouraging those within schools to develop reflective communities that are able to analyse and minimise barriers to the presence, learning and participation of their diverse members. It also analyses whether such reflective processes led to better understanding and practices in relation to diversity.

Keywords: Action research, attention to diversity, inclusive education, professional development, school improvement.
\end{abstract}

Resumen: Durante la última década, varios autores han considerado que para desamollar prácticas inclusivas es recomendable involucrar a la comunidad educativa en un proceso cooperativo de investigación, reflexión y acción en el que sus miembros adquieran aprendizajes sobre cómo atender a la diversidad de sus alumnos 
y alumnas. La investigación se llevó a cabo en dos escuelas en Chile (por motivos de confidencialidad, sus nombres son ficticios) con caractenísticas muy distintas: la escuela Innovación, en Santiago, es una de las escuelas del país con mayor experiencia en la integración de alumnos con discapacidad; mientras que la escuela Loncomahuida está situada en una de las áreas rurales más aisladas de Chile, a la que asiste un gran número de estudiantes de la etnia Mapuche.

El estudio está diseñado siguiendo una metodología de investigación acción. Ambas escuelas se involucraron en la implementación de un modelo inclusivo de investigación acción. Este modelo considera que es necesario concentrar los esfuerzos en la promoción de profesionales reflexivos, al igual que en el desarrollo de comunidades reflexivas. También implica que un equipo de co-investigadores, formado por voluntarios de las escuelas, interiorice y coordine el proceso en cada institución.

Se pretende contribuir con información sobre las estrategias sustentables que se pueden utilizar para involucrar a los diversos miembros de las escuelas en el desarrollo de comunidades reflexivas que sean capaces de analizar y disminuir las barreras a la presencia, aprendizaje y participación de sus miembros. Igualmente se analiza si dichos procesos reflexivos ayudan a comprender mejor cómo se puede atender a la diversidad en el aula y, en consecuencia, mejorar las prácticas educativas.

Palabras clave: Investigación-acción, atención a la diversidad, educación inclusiva, desarrollo profesional, mejora escolar.

\section{INTRODUCTION}

Since 1990, Chile has worked towards the construction of a democracy by trying to promote equal rights for all. Although the country and its citizens have still a long way to go, Chilean governments have embraced agreements and commitments declared by international agencies. In particular, the Ministry of Education has signed and followed UNESCO regional and international declarations and recommendations, based on the framework of 'Education for All' in 1990 and 2000. Inclusive education is one of UNESCO flagships in the Latin American region. This study has to be seen in relation to this wider policy context.

The study is built on the author's personal experience over the last few years. Although a Spaniard, we have been involved with Chile since 1997, firstly as an NGO volunteer, and later as a field officer for the UNESCO Regional Office of Education for Latin America and the Caribbean, situated in Santiago, the Chilean capital.

During the last decade the governments through the Chilean Ministry of Education have established close collaboration with UNESCO, in order to 
develop an educational system responding to diversity within a context characterised by hierarchical cultures and traditional practices. Ministerial actions have been focused on four different arenas: re-organization of the special education system; promotion of inter-cultural education; positive discrimination for schools in vulnerable situations; and the inclusion of the values of citizenship and democracy within the curricula. Nevertheless, there has not been an integration of these parallel strategies, and little has been done to promote the conditions of regular schools and the capacities of teachers in order to respond to the diversity of the students in their classes.

Set within this wider context, the study reported in this article intends to contribute to throw light on how Chilean schools and communities might develop sustainable inclusive policies, cultures and practices. For this purpose, inclusive education is taken to involve a process of analysing and minimising barriers to presence, learning and participation experienced by the members of an educational community. This requires schools to engage in a continuous process of change aimed at responding to all learners and reducing marginalisation and exclusion. Building on evidence from international studies, strategies are explored for encouraging schools to become reflective communities which are able to create ways of working that can reach every child, whatever their characteristics or personal circumstances.

In the last few years, some research literature has suggested that action research approaches and reflective processes can promote changes in the way schools address diversity. Family of approaches to action research were explored, in order to build up a theoretical framework which suggests that inclusive practices are more likely to be developed when those within school communities are involved in collaborative processes of inquiry, reflection and action, in order to learn how to respond to diversity. Based on the principles of action research, an inclusive action research model was designed, which guided the collaborative processes to be carried out in schools at three levels: at individual level, at community level, and with a coordinator team consisting of volunteer school staff.

Later on the evolution of the model as it was trialled in two different educational communities was analysed: Innovacion School, a middle class private school in Santiago, the capital city, and Loncomahuida School in a rural and underprivileged area in the south ${ }^{\mathbf{1}}$ with a high proportion of Mapuche people (means people of the land). The approach was aimed at facilitating reflection at an individual and social level. With this in mind, teachers and other professionals were provided with data gathered through observations, focus groups with students and staff, and activities with students as well. 
During individual interviews, group meetings and workshops, teachers reflected on their practices and the situation of the school considering actions for improvement.

Through the research, the purpose was to make direct contributions to the development of thinking and practice within particular contexts, whilst, at the same time, generating an understanding of how reflective processes contribute to transform teachers' understandings and practices in relation to the barriers of their students experience. We underlined the importance of creating the opportunities where teachers could confront defensive strategies which prevent them from being aware of how their attitudes and practices affect their students' learning processes. These are described as moments for reframing, when, either individually or socially, each teacher could question her $^{2}$ understanding from new perspectives. We argue that this process can lead to transformations in teacher's underlying theories and practical arguments, and, in some cases, to sustainable transformations in school cultures, policies and practices relating to the diversity of its members.

Some recommendations on strategies are provided for the promotion of school-based action research initiatives that foster schools' and teachers' capacities to improve the way they are responding to the diversity of their population in Chile. We recommend that it is crucial to implement particular conditions in schools, in terms of opportunities for professional development, time and space, which would facilitate reflection and learning amongst members, particularly in schools in underprivileged circumstances. Light is thrown on those aspects that schould be promoted in schools in order to minimise discriminatory attitudes, and contribute to the staff's commitment to adapt their teaching to the learning needs of their students. This would, we conclude, contribute to transform schools into democratic learning communities for all.

The characteristic of the study is that the research was developed in two very distinctive schools in Chile, therefore, these schools cannot be considered as representative of Chilean schools for the diversity of the educational contexts existing nowadays. However, a strength of the study is that for a long period of time this researcher was closely involved with the schools studied (which we think is unusual in educational research studies). As a consequence, the study makes well-informed suggestions about how researchers can collaborate in the implementation of action research processes that are flexible to school conditions, even in challenging circumstances. 


\title{
THEORETICAL BACKGROUND
}

\section{LATIN AMERICAN COMMITMENT TOWARDS EDUCATION FOR ALL}

To guarantee the goal of Education for All proclaimed at the world conference held in Jomtien, Thailand in 1990, representatives of the participant countries, Chile among them, agreed to commit themselves to guarantee the response to the basic learning needs of every child, young person and adult within a decade. On that occasion, the focus of the conference concentrated mainly on access to education for all.

Therefore, in 1994, UNESCO considered it necessary to hold yet another world conference in Salamanca, Spain, in order to work on the commitment of the right for quality education for all, especially for those with special educational needs. In the Salamanca declaration, the following extract is particularly relevant in relation to the characteristics of the populations that should be attending regular schools:

\begin{abstract}
"The guiding principle that informs this Framework is that schools should accommodate all children regardless of their physical, intellectual, social, emotional, linguistic or other conditions. This should include disabled and gifted children, street and working children, children from remote or nomadic populations, children from linguistic, ethnic or cultural minorities and children from other disadvantaged or marginalized areas or groups."
\end{abstract}

(UNESCO, 1994: 6)

We consider this aspect as central to the idea of inclusive education and attention to diversity, although it has not yet been achieved. The concept of special educational needs in the Salamanca Statement intended to change the perspective of students' differences, particularly the view of how to educate disabled students. Before 1990, in Latin America, education for disabled students was considered as remedial, in other words, education was seen as the means to fix what was wrong with these students. Disabled students had to be medically diagnosed, and the educational plans which students followed would be guided by their statements. In most of the cases, they would be taught in segregated special schools or classes, and would be under the responsibility of a special teacher or other professional (UNESCO, 2001).

The inclusion of the special educational needs concept at the Salamanca Conference, following the arguments of the Warnock Report (DFES 1978), had the purpose of underlining that regular schools should be responsible for 
the learning processes of every student, independently of their individual characteristics or their medical statements. In this sense, representatives of the Salamanca Conference tried to provide a pedagogical framework to move from the deficit or medical model of differences, which underlines that it is the individual who has the problem that prevents him her from learning, towards a social model which considers that any individual faces barriers to learning due to the conditions in the schools and classes, and the educational responses they receive. For this reason, in order to respond to the students' educational needs, schools should organize their resources and make use of the resources provided by the community (MNEDUC, 2004a) with the aim of creating the conditions where every student can learn.

Despite the emphasis stressed by the Salamanca Statement, during our time working in the Department of Inclusive Education for UNESCO, we observed that in the Latin American region most of the efforts to promote inclusive education were addressed towards the integration of disabled students into regular schools (Blanco, 2000). This has been a major achievement, since the percentage of disabled students on mainstream programmes has increased considerably since 1990 (UNESCO, 2001; MINEDUC, 2004b). 68,820 disabled students attended education in 2004, with 20,746 of them in regular schools. In 1997, the number of integrated disabled students was only 3,365 (MINEDUC, 2004b).

Nevertheless, many educational actors had adopted the terms inclusion and special educational needs (SEN) as synonyms for integration and disabilities(UNESCO, 2004). In addition, those schools responding to integrated students, as they are called in Chile, have adopted pedagogical strategies based on individual responses to students with SEN. Regular teachers have a low participation in their education, as they generally consider that students with SEN are the responsibility of the special teachers or other support professionals. Furthermore, homogenizing educational approaches are still common (UNESCO, 1999; MINEDUC, 2004b), and educational systems and schools have not taken into consideration other characteristics of students, such as gender, ethnicity and socio-economical background, in order to adapt the curriculum and the educational plans to the students' needs. 


\section{ATTENTION TO DIVERSITY AND INCLUSIVE EDUCATION}

The phrase attention to diversity is a term broadly used in Latin America and Spain, and goes beyond inclusive education in a number of ways. It responds to the particular characteristics of cultural contexts, and to the structure of educational systems.

It has become a theoretical concept that intends to respond to a transformation of the structure of educational systems. These systems, we consider, are characterised by separate educational departments that work in isolation, responding to particular populations in danger of exclusion, for example, special education, intercultural education, education for poor populations, and gender, among others.

We observed this situation in the Chilean educational system. In the last commission, already mentioned, constituted by relevant actors in education, it was suggested that attention to diversity should guide the articulation of policies and educational departments towards interdisciplinary actions, with the purpose of establishing a more coherent and adequate educational response for all (MINEDUC, 2004b).

Attention to diversity requires, therefore, an articulation of the educational system. Furthermore, it underlines the importance of creating within schools an emotional climate where each member feels a sense of belonging, and works to construct a community where everyone can learn and participate (Blanco, 2000, 2005; Echeita and Sandoval, 2002; Echeita, 2006).

"(...) it is the school that should adapt itself to the needs of the students and not the students who adapt to the requirements of the school."

(Blanco, 2000: 41)

For this to happen, efforts to promote attention to diversity cannot be concentrated, in our opinion, on particular school members; it requires the whole school community to engage in a process of development and improvement. In the last decade, some inclusive education authors have stressed the argument that action research approaches can support schools becoming inclusive communities (Ainscow, 1999, 2002; Booth and Ainscow, 2002; Ainscow et al., 2003).

Inclusive education authors state that schools and teachers have the resources and the knowledge to create the conditions where students can 
learn and participate, independently from their individual characteristics. They stand on a social model or organizational paradigm which considers that it is the organization which needs to be transformed in order to adapt to the individual learning needs of their students.

Through the analysis of inclusive education literature, inclusive schools are characterised by a central philosophy and strong beliefs in values of respect to diversity, collaboration, participation, equity and solidarity (Dyson and Millward, 2000; Dyson etal., 2002; O'Hanlon, 2003; Armstrong and Moore, 2004; Ainscow, 2006; Ainscow et al., 2006).

This common ethos considers the learning process of each individual as central in the school decisions and practices (Corbett, 2001; Kugelmass, 2001). Inclusive schools become then highly committed educational communities which promote the active participation of teachers, other educational professionals, students and parents, whilst minimising discrimination and exclusion. An open climate of communication and collaboration is established among staff members and students (Kugelmass, 2001; Dyson, et al., 2002), which leads to the creation of learning communities where their members are challenged to reflect on the barriers to presence, learning and participation experienced in order to take further steps towards inclusion (Ainscow 1999; 2002; 2004).

\section{CHILEAN NATIONAL CONTEXT}

In the last seventeen years, with the return to democracy, governments through the Ministry of Education have worked to widen access to education for all, with what we consider successful results. Nevertheless, we perceive that the Chilean government currently faces the challenge of achieving equal quality education for all. In our opinion, inclusive education principles and practices could be a key factor in pursuing improvement of quality with equity.

Since then, the role of the state has become one of promotion, in the sense that it has assumed the responsibility for provoking radical changes in the area. In order to pursue quality of education with equity, the educational policies have concentrated on schools (Baez, 1999). These policies have materialised by means of universal programmes, like the Programmes for the Improvement of Quality of Education (Mejoramiento de la Calidad de la Educación, MECE), MECE Básica and MECEMedia (for primary and secondary schools); and specialised programmes, as P-900, the programme of the 900 schools, Rural Education, Liceo para todos (secondary school for all), 
integration programmes for disabled students since 1997, and Programa Orígenes for ethnic communities. Among the aims of these programmes is the promotion of schools' autonomy (UNICEF and MINEDUC, 2004).

Despite these efforts, there are still huge transformations to be made in order to continue improving an education system that is still fundamentally exclusive. Governments have tried to deal with inequalities through different departments and educational programmes. Nevertheless, it has not contributed towards the reorganization of an inclusive education system with an articulated response to the diversity of its learners (Ainscow, 2004).

Furthermore, a recent evaluative report by the Ministry of Education and the OECD has concluded that the educational reform and its principles have not reached the classroom (OCDE and MINEDUC, 2004). Promoting transformations in the way schools and teachers are responding to the learning processes of their students is central in our research.

Considering teachers and other professionals, Avalos (2004) underlines that the conditions for professional development being implemented by Chilean governments have contributed to a transit from an in-service training based on a deficit theory, which considers that teachers need to be taught what they do not know, towards a continuing professional development aiming to empower and strengthen teachers' capacities through team work and interchange of experiences. We believe that despite the efforts, there is still a long way to go in the reinforcement of teachers' professionalism, self-esteem, autonomy and innovative thinking.

\section{School-based programmes for improvement}

In April, 2007, the government presented the new law proposal that establishes the Ley General de Educación (General Law of Education). This new law is a response to secondary students' national demonstrations against the education system which took place from April to August in 2006. In our opinion, this proposal responded to a new democratic climate built up in the last seventeen years. In what follows, we concentrate on those aspects underlined in a new General Law of Education which would foster the evolution of an inclusive education system.

The Ministry of Education in Chile has concentrated its actions on schoolbased programmes to spread the curricular reform, and to promote educational improvements and innovations. The development of school capacity and autonomy in administrative and pedagogical matters has been maintained as 
a crucial strategy in the new proposal of the General Law of Education. The document requires from each school the obligation to develop an Institutional Educational Project, or PEI (Proyecto Educativo Instituiconal), as part of the criteria to be registered by the Ministry of Education as an official educational institution. In addition, the new law implements strategies to enhance the participation of community members through the establishment of school governing bodies.

These school-based incentives intend to promote autonomy and professional development among the members of each educational community. According to the knowledge gathered through our research, school conditions that facilitate collaborative action research processes should be created by allocating time and resources for collaborative reflection and work.

\section{THE STUDY}

\section{PURPOSES AND RESEARCH QUESTIONS}

Committed to the principles of attention to diversity and inclusive education, and faced with the challenges of the Chilean education system, the purpose of this research is to throw light on how schools and educational communities can develop sustainable inclusive policies, cultures and practices. With this in mind, it explores strategies for encouraging schools to become reflective communities which are able to create ways of working that can reach every child, whatever their characteristics or personal circumstances.

The research was guided by a theoretical framework which suggests that inclusive practices are more likely to be developed when those within school communities are involved in collaborative processes of inquiry, reflection and action in order to learn how to respond to diversity. The research intends to answer:

- What conditions are necessary in order to develop collaborative reflective processes in addressing diversity within Chilean schools?

- To what extent do such processes lead to better understanding and practices in relation to diversity?

This study aims to contribute to foster teachers' professional development and school improvements. This is in tune with one of the political priorities stated through the Ministry of Education: the promotion of autonomy and capacity building within schools in order to create equal opportunities for learning for all. Transformations achieved at school level, as well as the knowledge gathered from the research, can demonstrate that the promotion 
of reflective processes have positive effects on the development of school staff's professionalism and school re-organization, with resources that are reasonably available within the Chilean context, even in those schools in disadvantage areas.

The strategy that guides this research concentrates on the principles of inclusive education and attention to diversity, and analyses whether these values are put into practice by scrutinising the barriers to presence, learning and participation experienced by school members; this strategy can help teachers and professionals transcend from an individual model of students' differences, focused on fixing students' individual problems, towards a social model which underlines the need to make better use of the resources available in the school and in the local community, in order to respond to students' learning processes.

\section{THE INCLUSIVE ACTION RESEARCH APPROACH}

The methodological design of our research is based on the philosophy behind the Index for Inclusion (Booth and Ainscow, 2002). The Index is a set of materials which were developed over a period of three years under the coordination of the Professors Mel Ainscow and Tony Booth by a team consisting of teachers, parents, members of school councils, researchers and representatives of organizations of disabled people with experience in inclusive initiatives.

Given its relevance, in May 2000, the British Government distributed the Index to each school and LEA (local education authorities) in the country. The use of the materials by schools and LEAs seems to have had a positive impact on the development of inclusive cultures and practices within educational institutions in the United Kingdom.

One of the first aspects that attracted our attention to the Index was that its authors use the concept of barriers to presence, learning and participation to refer to those difficulties experienced by any member of an educational community. These barriers can be caused by the interaction of each person with her context. It is recognised that people's lives are affected by individuals, policies, institutions, cultures and social and economical circumstances.

The Index material focuses particularly on the analysis of those barriers that emerge from the school cultures, policies and practices. It invites schools to engage in an on-going process of change and improvement (Ainscow, 2002; Booth and Ainscow, 2002; Ainscow, et al, 2006). 
Based on this argument and structure, we followed the theoretical and practical features of action research in general, and in particular Participatory Action Research (PAR); co-operative inquiry; action inquiry/action science; and educational action research approaches which informed this methodology. It involved the following principles and purposes: research with people, particularly those in vulnerable situations; establishing equal power relationships; promoting collective and individual reflection; fostering change; and producing valid knowledge.

We also considered that our own role as an outside researcher presented two aspects of our concern. The first one was the community members' perception of our self-hood (Bell et al., 1993). The fact of being a foreigner (Spaniard) could lead community members to understandable tensions against a 'female colonialist university researcher trying to teach them how to do their work, or even how to live their lives'; we were aware that it was necessary to avoid members of the community this reactivity towards an outsider (Pryor, 1998).

To acknowledge the impact of the presence of the researcher is an issue that authors from feminist approaches consider essential in order to establish an authentic and collaborative relationship in the fieldwork (Finch, 1992; Bell et al., 1993; Karim, 1993; Mcauliffe and Coleman, 1999). This tradition argues that the researcher needs to describe, acknowledge her situation, her influence on the researched, and the difficulties of being, at the same time, researcher and part of the phenomena under investigation.

Researchers of this tradition use a reflexivity perspective in order to develop the research and analyse the phenomena. As they consider that the researcher is one of the main actors of the phenomena, they write accounts about themselves. So we perceived the need to use this strategy as an alternative in the design of the model, with the aim of becoming consciously aware of the power tensions and attitudes that our presence and behaviour might have, and consequently take appropriate actions.

The second aspect is that we were having a double agenda. The purpose of this research was to implement the inclusive action research process in both educational communities. In this case, data gathering was merely the means to contributing to the reflective process, but at the same time, the aim of the study was also to get a $\mathrm{PhD}$; dual role, as facilitator of the research, and as an ethnographer, gathering data to present a reliable and valid case to academic researchers and, therefore, to contribute to knowledge. We were interested in gathering knowledge about the facilitator roles of researchers in 
promoting action research, described by Elliott (1991) as a second order action research. For this reason, we were aware of the control needed to keep over the data gathering and analysis, in order to record the process and gain an understanding of what happened during the implementation.

We sought to design an inclusive action research framework which could respond to all these aspects and the inclusive principles. It was important that the framework could adapt to the context and the situation of different educational communities, and from that point of view, it was necessary for school members to be involved. For this reason, we understood that the approach needed to respond to their agendas, or in other words, that the members of the communities needed to find the approach useful and relevant for them.

One of our main concerns when designing the inclusive action research model was to make it sustainable over time. The main question in mind was: how can inclusive reflective capacities be created and developed and be maintained over time? Therefore, we considered that a three-level approach based on active participation of community members would guarantee the sustainability of the process.

The design of the inclusive action research model planned to be implemented in both schools is presented in Figure 1. We endeavoured to visualise a holistic panorama of those community aspects that could support the transformation of schools towards inclusion. The research model to be developed in both schools had different areas of action and promoted three levels of reflection on attention to diversity. 


\section{Figure 1. First design of the inclusive action research model}

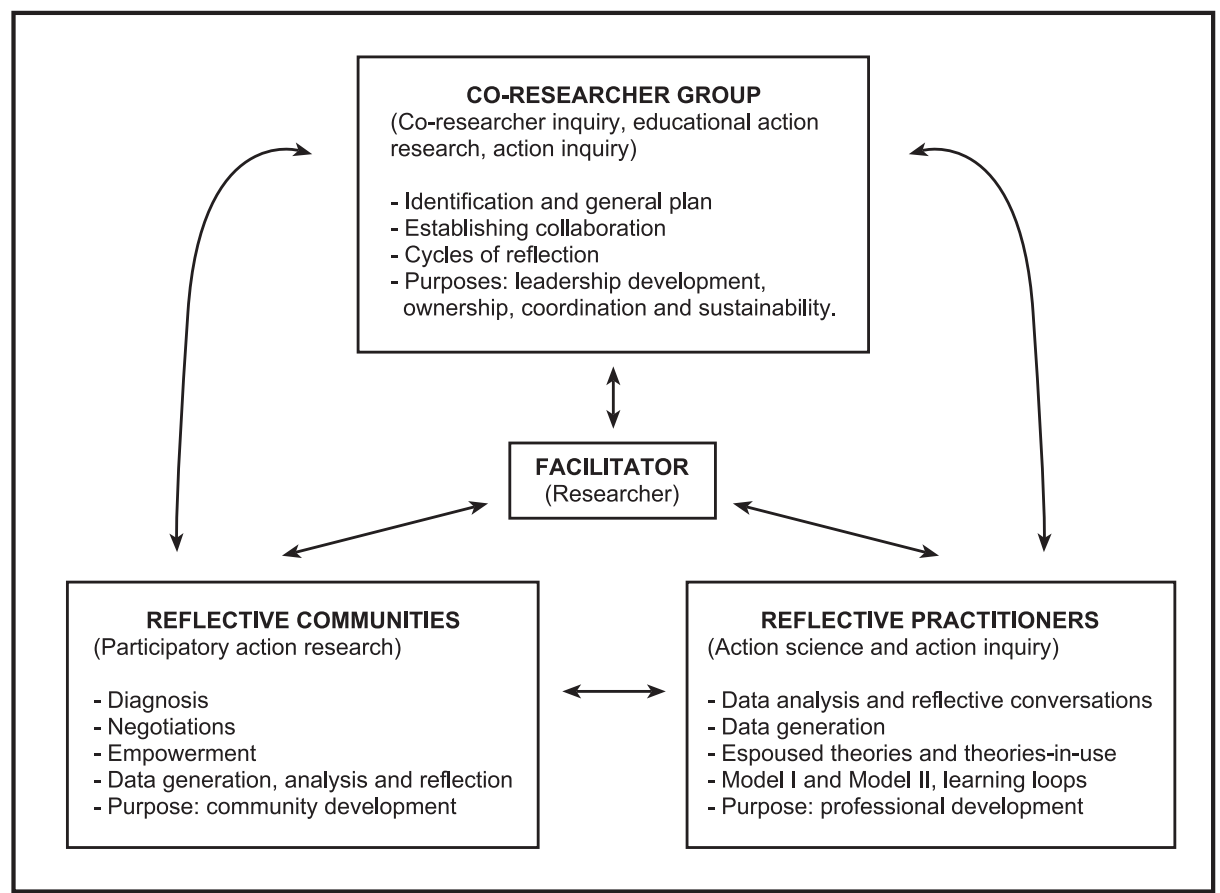

At an individual level, off-line reflective interviews (Rudolph et al., 2001) with teachers and other professionals were designed following Schön's (1983) theories about the reflective practitioner, and the theories of the Models of Theory-in-Use (Argyris, et al., 1985), and learning loops (Torbert, 2001) from action science and action inquiry. Through this perspective, educators and other professionals would be able to analyse the variety of personal governing frames (Argyris et al., 1985) and understand how their underlying theories (Schön, 1983, 1991) have had an impact on their reflection and in their practices attending to diversity.

At community level, a participatory action research approach (PAR) (Fals Borda, 2001; Wadsworth, 2001) was followed to hold community reflective meetings where different members of the educational community could discuss the data collected; learn from the different learning materials presented; reflect on their practices and the challenges faced; and plan future actions. Through systematic collaborative reflection, it was considered that they could understand the barriers to learning and participation faced by students, teachers, staff, and parents. They could also get involved in a learning process, creating knowledge (Lather, 1986; Gaventa and Cornwall, 2001; Park, 2001) about how to respond to these barriers, and change their cultures, policies and 
practices to improve them. The approach was planned to challenge their consciousness, their knowledge and their actions (Gaventa and Cornwall, 2001).

In addition, in order to coordinate the approach in each school, a group of co-researchers was organized and developed. This team would have active part in the design of the inclusive process, making decisions about the aspects to analyse, the people to be involved, the methods to be used, and the action plan to be carried out. Theories of co-researcher inquiry (Reason, 1998; Gustavsen, 2001; Heron, 2001; Heron and Reason, 2001), educational action research (Carr and Kemmis, 1986; Elliott, 1991; Kemmis, 2001; Zeichner, 2001) and action science (Torbert, 1991; 2001) were followed in this matter.

In short, we find that the interconnections of the different approaches of action research could build up an inclusive action research approach that promotes participation and the involvement of different members of the educational community, especially those facing barriers to presence, learning and participation. We also sought to create an approach that contributed to the educational communities by means of reflective spaces which lead to changes and transformations in their practices, cultures and policies. And finally, the inclusive collaborative action research approach was aimed to be adopted by the members of the community and become a sustainable process as part of the educational plans of the schools.

\section{METHODS TO GATHER KNOWLEDGE FOR REFLECTION AND TO UNDERSTAND THE EVOLUTION AND IMPACT OF THE APPROACH}

As explained earlier, the principal aim of the research was to promote reflection, individually and in groups, among the members of the educational communities. We had observed in earlier research that evidence elicited in the school could provide information to analyse cultures, policies and practices. The methodological strategies aimed at gathering evidence for reflection were: focus groups with staff and students; photographic activities and games with students; and participant observations in classes and school life.

In Chile, we told the teachers and the other professionals in each school that the evidence gathered could be seen as radiography or a mirror in which they could examine the aspects they needed to take into consideration to implement improvement.

The variety of the population involved and the activities carried out were dependent on the interests of each school. Most of the teachers in 
Loncomahuida School wanted to be observed in order to get suggestions for improving their practices. We observed classes with every early childhood educator and secondary teacher, as well as a large number of primary teachers. In Santiago, the educational psychologist and the members of the coordination team were willing to listen to the opinions of other colleagues; therefore we held focus groups with the Thecnical Pedagogical Unit (TPU) professionals, and primary and secondary teachers.

In addition, we used other methods for data gathering in order to understand the development and impact of the inclusive action research process: documentary analysis; interviews; participant observations in meetings and workshops; and our researcher's diary.

\section{THE EVOLUTION OF THE INCLUSIVE ACTION RESEARCH MODEL}

\section{THE INNOVACION SCHOOL - A MIDDLE CLASS PRIVATE SCHOOL}

\section{Conditions in which the model evolved}

Some of the school conditions seemed to have created a situation whereby the inclusive action research model would evolve in this particular way. It appeared that this school regarded itself as having a strong identity, a sense of belonging, and a commitment to, as well as participation with its members. It had been open to diversity since its origins and its members had worked as a community to improve their response. The headteacher, the Technical Pedagogical Unit (Unidad Técnica Pedagógica-UTP) members and some teachers appeared to have a clear determination that the process would lead them to an educational innovation on attention to diversity, in order to diversify their educational practices, gather autonomy, and minimise the tensions in relation to the external support team of the school.

The evolution of the inclusive action research model in Innovacion School can be seen in Fig. 2. It provides a representation of the model presented earlier within the context of this particular school during the case study process. 


\section{Figure 2. Emphasis on the evolution of the inclusive action research model in Innovacion School}

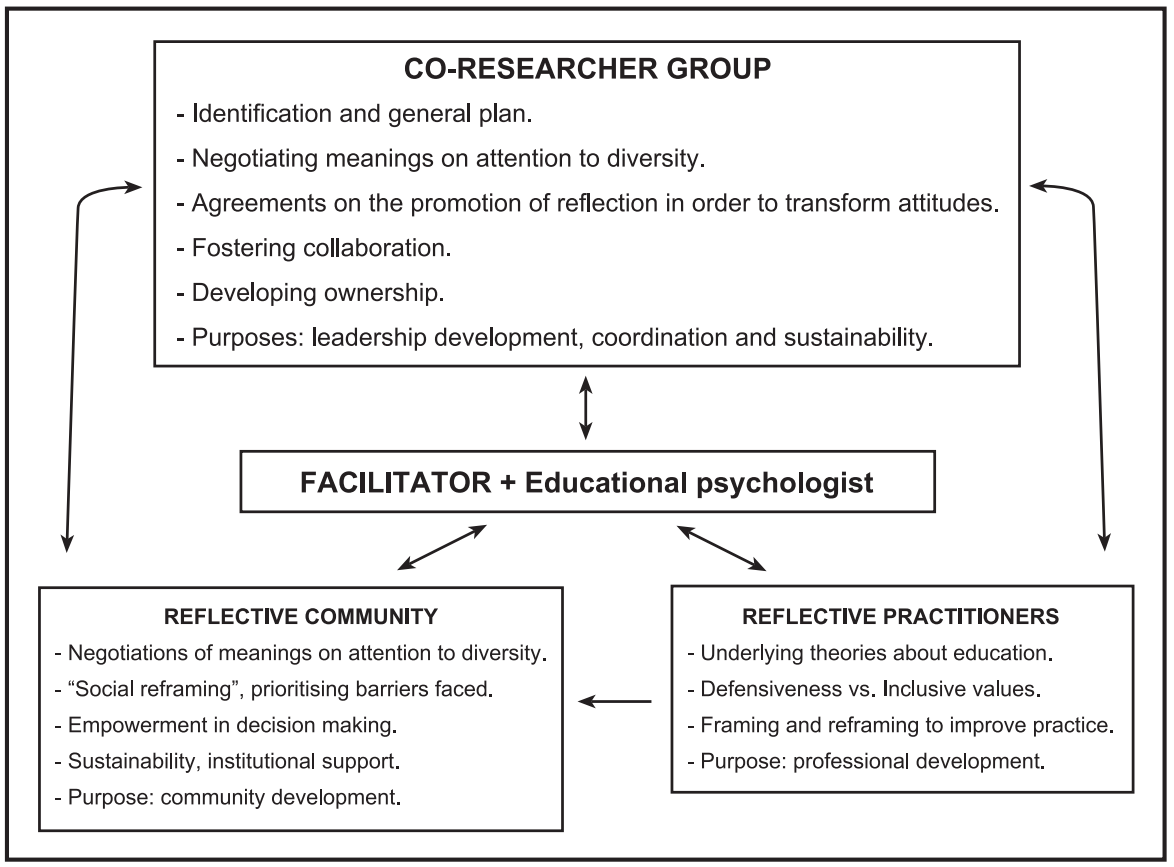

Fig. 2 shows that most of the work appeared to have concentrated on the development of the coordination group. The role as facilitator was shared with and dependent on the collaboration with the educational psychologist of the school. The strongest bilateral relationships seemed to be established with the coordination team members, the co-researcher group in Fig. 2 in order to promote their leadership role, make decisions about the process and organize the final workshop.

According to our interpretation, the meetings with the coordination team were useful to establish further conditions for the evolution of an action research process. The coordination meetings served to promote team work and transformational leadership. They were the instances where teachers seemed to share a sense of belonging to the group and the school, and it appeared that the meetings helped to promote collaboration among teachers. It became apparent that the participants owned the process and made decisions about the development of their community in relation to attention to diversity.

Teachers' reflections in the initial meetings, we believe, helped the coordination team, the educational psychologist and the researcher to define 
the indicators to be analysed. Although we had the impression that the promotion of individual reflective practitioners was not perceived as a priority, five reflective interviews were carried out which enlightened us about the aspects on which to concentrate with the coordination team and in the reflective workshop. Additionally, those involved in the reflective interviews appeared to contribute to some degree in the reflection and decision making of the coordination team. They also played a strong leadership role in the final workshop.

The promotion of the reflective community consisted of the initial and final workshops with teachers. In these events, a climate of rapport, trust, openness and common understanding was perceived, and teachers seemed to be empowered to be able to talk about the situation of their school, discuss their opinions with other colleagues, and decide on lines of action.

We recognise that one of the difficulties that the model faced was paid time allocation for the educational psychologist's coordination, and for the meetings to take place with the coordination team. But above all, although the institutional support of the pedagogical management team appeared to be crucial in the evolution of the process, its control over it could also jeopardize its development and the involvement of other community members in the decision making and the implementation of a sustainable inclusive plan for the school.

\section{Contributions of the model to understandings and practices in relation to diversity}

During the nine months of collaboration with the school already described, a transformation in the way the community understood diversity was evident. At the beginning, their worries seemed to be related to disabled students and those considered having special educational needs.

Through the cycles of individual and collaborative reflection, and faced with the evidence gathered in the school, the teachers considered that attention to diversity was related to the argument that all students should receive a quality education. They jointly constructed a common knowledge about how their practices should evolve and how the school should create the conditions to make this sustainable over time.

The cycles of individual reflection to promote reflective practitioners were a help to understand the teacher's underlying theories or/and practical arguments about education and attention to diversity. In the light of the class 
observations, we could visualise how some teachers used defensive strategies to justify the exclusion of disabled students from their educational practices. In other cases, teachers appeared to show that their inclusive values promoted reflection-in-and-on-action that helped them to adjust their educational practices in order to respond to everyone.

The defensiveness expressed by teachers was interpreted as a response to the feeling that they were not responsible for those students who faced barriers to learning and participation. This defensive strategy prevented individual teachers reflecting on their understandings and being able to see their practices from other perspectives. The coordination meetings and workshops seemed to provide teachers with an opportunity to share their insights with other colleagues who could help individuals socially reframe their ideas, beliefs and attitudes.

It became apparent how important the role of the coordination team was in the transformation of ideas about how Innovacion School should respond to the diversity of its members. They seemed to discuss meanings about attention to diversity and the need to promote reflection in order to change the defensive attitudes of some of their colleagues. In addition, they seemed to assume the responsibility to design and implement an inclusive education plan for the school. With this purpose in mind, they considered the lines of action which had been agreed, and prioritised in the teachers' workshop.

As can be seen in the lines of action presented below, teachers appeared to be focusing on reorganizing their practices and exchanging their knowledge in order to respond to everyone.

"Culture dimension, line of action: Teachers need to be more proactive in solving small problems that we pass on to the TPU. Policies dimension, line of action: Collaborative work to interchange and register our experiences.

Practices dimension, line of action: Promote a self-managed and collaborative professional development."

(Final workshop report, $15^{\text {th }}$ July, 2005)

In our opinion, at the final workshop, the teachers emerged with common agreements about the most important barriers and facilitators existing in the community, and also made themselves responsible for those aspects they could tackle through their individual practices. They designed lines of action in relation to the school organization and structure. Teachers seemed to be willing to guarantee a sustainable transformation of the school towards more 
inclusive practices, under the leadership of the coordination team, and with the institutional support of the headteacher and the professionals of the TPU (technical pedagogical unit).

\section{THE LONCOMAHUIDA SCHOOL - A RURAL SCHOOL}

\section{Conditions in which the model evolved}

The particular characteristics of this school meant that the inclusive action research process was largely dependent on this researcher's involvement, and concentrated on the promotion of reflective communities and the development of reflective practitioners. The school was part of a NGO programme that over the last decade had a strong impact on its mission and structure. The priests and the members of the NGO inculcated Catholic values based on freedom, justice and solidarity, and gave special importance to the recuperation of the Mapuche language and culture.

Nevertheless, during our fieldwork, the school suffered a strong structural crisis and faced serious tensions that hindered the participation of its members. The hierarchical culture and tensions among groups of teachers were demonstrated in their attitudes and practices towards diversity. Discrimination and segregation seemed to be common barriers to the presence, learning and participation of a number of students, among them, disabled children and teenagers. In addition, we believe that the teachers' living conditions and professional development were tough, which affected their motivation and performance in class.

The introduction of the inclusive action research model was possible through negotiations with the educational management team at the school and in the introductory meeting with the teachers. Due to difficulties in organizing and meeting the voluntary members of the coordination team, this researcher became the one who coordinated the approach and adapted it to the timetable and structure of the school. Meetings with the educational management team seemed to be useful in making decisions about the three school workshops held. Assistance at the meetings of each school level was necessary, to coordinate the action research process with each team and to carry out group reflection.

In Fig. 3, the evolution of the inclusive action research model at this school is presented. 


\section{Figure 3. Emphasis on the evolution of the inclusive action research model at Loncomahuida School}

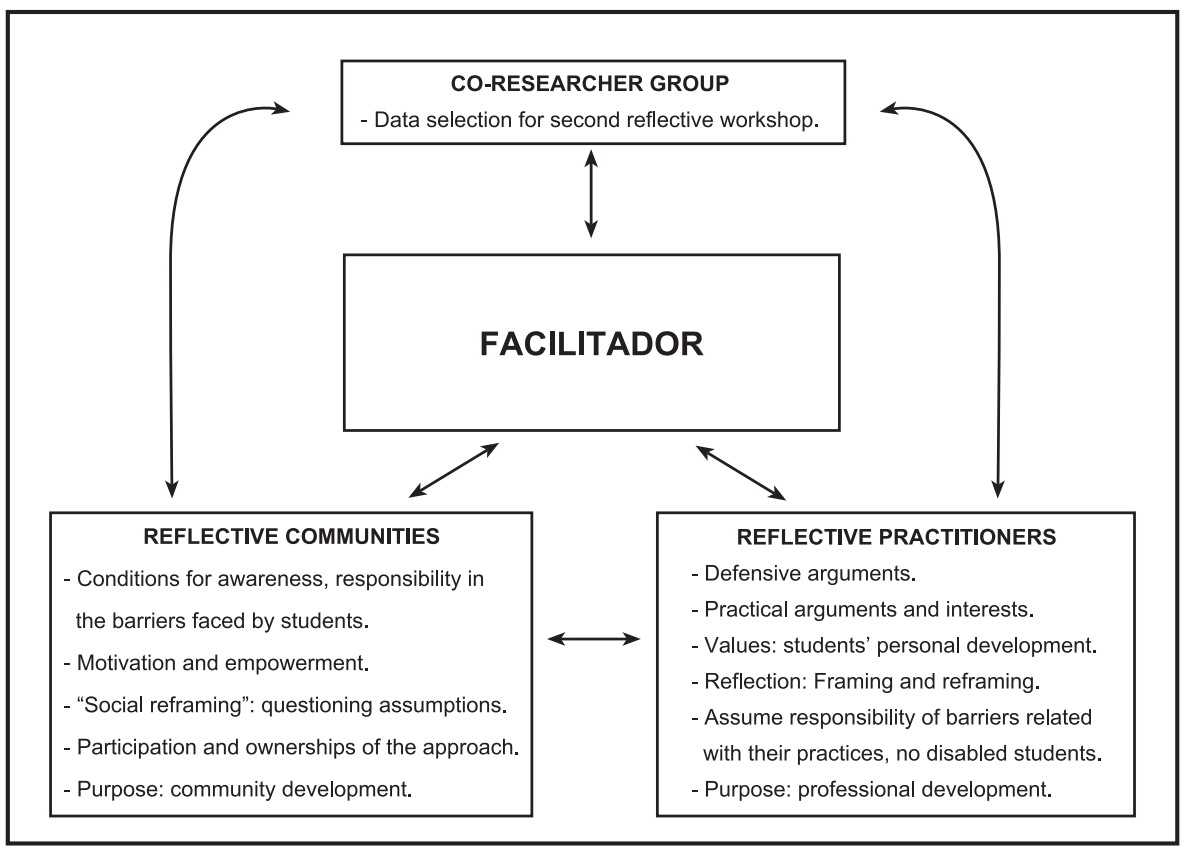

The coordination team, or co-researcher group, contributed to select the data and the topics for reflection in the second workshop assisted by this researcher. The participation of the members of the team in reflective interviews, meetings and workshops appeared to enhance their agency to make decisions about this particular workshop. Reflective interviews were organized and carried out with the purpose of promoting reflective practitioners. As the teachers had taken part in the first workshop and the reflective meetings previously, they seemed to be more sensitised to the topic when we held individual interviews. At the same time, it became apparent that engaging teachers in individual conversations about their practices also facilitated teaching taking an active part in the subsequent meetings and workshops for reflection. The information gathered from the co-researcher group, the interviews, meetings and workshops gave new insights about areas to include, data to analyse and the learning materials to be used in the subsequent reflective events. 


\section{Contributions of the model to understandings and practices in relation to diversity}

As noted in Fig. 3, interviews were held where teachers could reflect on the accounts of the observation of their classes. The purpose was to promote professional development by engaging teachers in a process where they could frame and reframe their understandings about their practices, using different perspectives for improvement. Most teachers seemed to use defensive arguments, considering that the barriers to presence, learning and participation of their students were due to factors out of their control. In these cases, it was found difficult to help them become aware of their responsibilities as to the barriers faced by their students.

Other teachers were able to analyse their practical arguments and their interest when attending to diversity in their classes. Reflection on the individual needs of particular students appeared to be more common among those teachers with interests and values closely linked to the individual development of their students. Nevertheless, we became aware that teachers did not feel they had the competencies to reflect on how to accompany the learning process of the disabled students.

The promotion of the reflective community was possible through three reflective workshops and meetings at each phase of schooling, and teachers were provided with evidence and training materials to reflect on the barriers faced. Given the school conditions, we interpreted that these activities were useful in establishing the basis for the first steps of the construction of a learning community that attended to diversity. They were designed to create an atmosphere where teachers felt comfortable to participate, express themselves, and work in groups. They demonstrated that they felt motivated into sharing their feelings, concerns and opinions. It appeared that the activities promoted agency and capacity building, and teachers felt empowered to give suggestions to their colleagues and also to design actions to be put into place in their classes. In each school team, teachers also made decisions about the action research process; considering the aspects to be analysed, the classes to be observed, and the populations with which to become involved. Nevertheless, they did not seem to provide comments about aspects related to the organization of the school. For example,

"I realised that one is able to reflect and give opinions about one's educational practices."

(Teacher's evaluation sheet, second reflective workshop, $20^{\text {th }}$ June, 2005) 
In our opinion, there were two major interlinked results of the meetings and workshops which enhanced community development. As described in Fig. 3, the teachers seemed to become more aware that their attitudes and practices influenced the learning processes of their students. We believe that they were taking the first steps in questioning their own defensive arguments. As one teacher expressed to his colleagues in the last workshop,

"We have to assume how much of this situation is due to us, that is what this work is about, instead of getting stuck in the difficulties that come from outside."

(Report of third reflective workshop, $12^{\text {th }}$ August, 2005)

This seemed to be possible due to the opportunities that the group discussions gave for social reframing, which meant that each teacher had the opportunity to see their beliefs and underlying arguments about education and diversity in the light of other perspectives that came from their colleagues, the evidence and the training materials provided. Teachers reflected on their attitudes and behaviour, and their teaching strategies in order to respond to their students. Our impression was that they also came to agreements on the values and practices that Loncomahuida School should promote, which seemed to foster a sense of identity and belonging among teachers. In spite of these first movements forwards, they did not, however, seem to be prepared to reflect and analyse the barriers faced by their disabled students. In addition, the teachers interviewed and this researcher had serious doubts that the action research process would have any continuity without professional support.

\section{LESSONS LEARNT}

Fig. 4 represents a revision of the inclusive action research approach in light of the analysis of its evolution in each school. The figure points to changes in understandings and practices witnessed in the promotion of reflective practitioners, reflective communities, and a co-researcher team in each of the two schools included in the study in Chile. In what follows, these processes are explained in detail by discussing each level presented in the model. 


\section{Figure 4. Revision of the inclusive action research model}

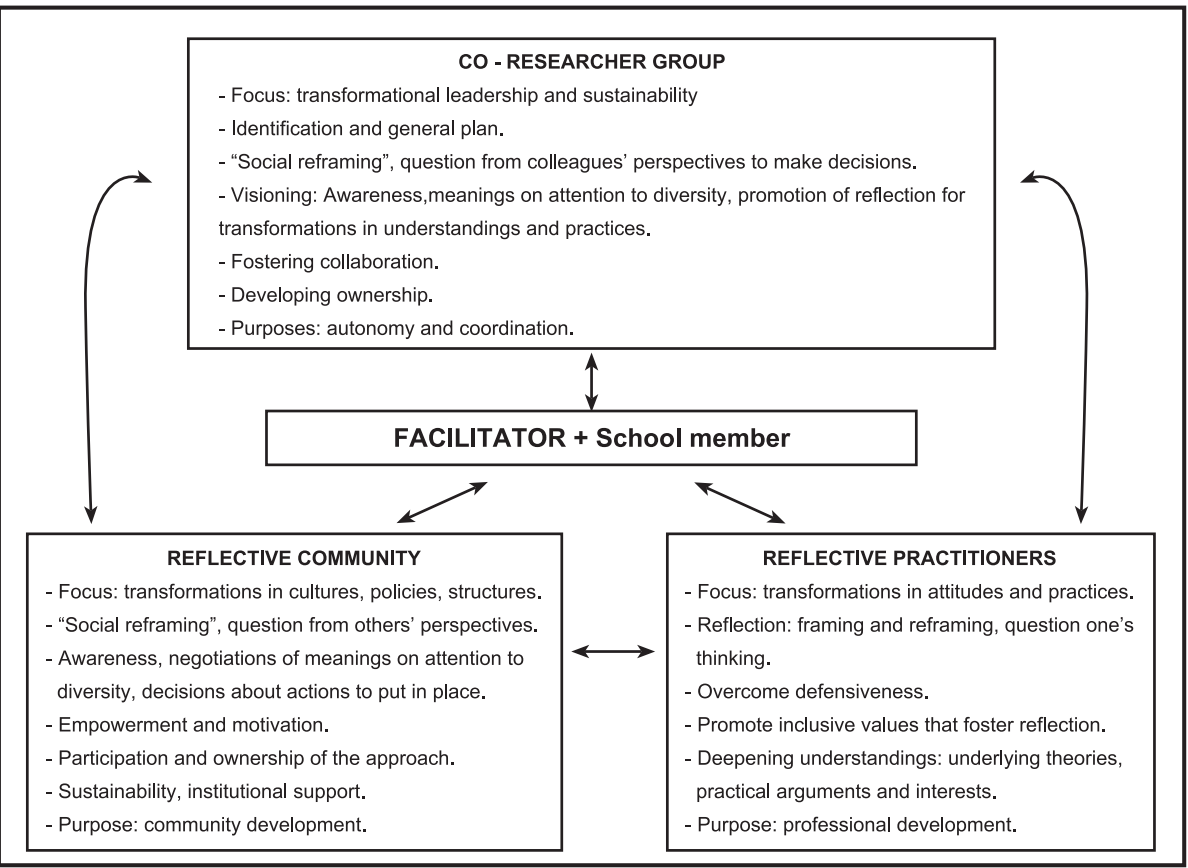

\section{TRANSFORMATIONS THROUGH INDIVIDUAL REFLECTION}

Examining individual teachers, the research adds support to the argument that reflection is central in order to produce transformations in thinking and practice. This also links to the view that teachers need to engage in individual reflective processes where they question and reframe their understanding about attention to diversity and education.

It became apparent that teachers follow different reflective pathways when confronted by the facilitators and barriers experienced, as they try to respond to the diverse learning processes of their students. In some cases, teachers use defensive arguments by claiming that the barriers faced by their students are out of their control. Teachers' defensiveness seems to prevent them from thinking analytically about their practices and seeing the aspects they could improve.

Transformations in teachers' understandings seem to be promoted when teachers have a set of inclusive values that make them assume the responsibility 
of responding to their students' learning processes. These teachers also appear to value reflection as a process for improvement.

Those teachers, who apparently were able to reflect, thought analytically and questioned their underlying theories, their practical arguments and their interests in education and the learning experiences of their students. Individual transformations in understandings were observed, but not in educational practices.

\section{TRANSFORMATIONS WITHIN THE EDUCATIONAL COMMUNITY}

In relation to educational communities, the research concludes that transformations appeared to be possible by creating opportunities for social reframing, where school members question their assumptions, theories and beliefs by considering other colleagues' opinions. These instances seemed to enhance a sense of belonging amongst participants and their commitment towards a common cause.

Through the inclusive action research process, school members may increase their awareness and responsibility about the impact that their attitudes and behaviour have on the barriers perceived in the community. Participants can negotiate those meanings about education and attention to diversity that should guide the endeavour of the school. They may also feel motivated and empowered to participate and make decisions about the inclusive action research process, and about transformations to be carried out in the school.

Through these opportunities for social reframing, some changes in understandings and practices in both schools were perceived. These are summarised in the following table. 


\section{Table 1. Comparisons of transformations in understandings and practices observed in each of the two schools of the study}

\begin{tabular}{|c|c|c|}
\hline Transformations & Innovación School & Loncomahuida School \\
\hline Understandings & $\begin{array}{l}\text { Negotiations of meanings on } \\
\text { attention to diversity: } \\
\text { - Inclusive education, not only } \\
\text { for students with special } \\
\text { educational needs but for all. } \\
\text { - Awareness of teachers' } \\
\text { attitudes and practices as } \\
\text { barriers. } \\
\text { - Teachers' responsibility: every } \\
\text { student, no matter their } \\
\text { individual characteristics. } \\
\text { Social reframing, prioritising } \\
\text { barriers faced. } \\
\text { Unsettled, willing to know more } \\
\text { about how to attend to each } \\
\text { student's diversity. }\end{array}$ & $\begin{array}{l}\text { Negotiations of meanings on } \\
\text { attention to diversity: } \\
\text { - Creating the conditions for } \\
\text { awareness, teachers' } \\
\text { responsibility in the barriers } \\
\text { faced by students. } \\
\text { - Teachers' responsibility: those } \\
\text { students in class, not disabled } \\
\text { students. } \\
\text { Social reframing: questioning } \\
\text { assumptions, beliefs and values. } \\
\text { Unsettled, willing to know more } \\
\text { about how to attend to each } \\
\text { student's diversity. }\end{array}$ \\
\hline Practices & $\begin{array}{l}\text { Empowerment, autonomy and } \\
\text { participation in decision making: } \\
\text { - changes in individual practices; } \\
\text { - organization of school } \\
\text { professional development } \\
\text { opportunities based on } \\
\text { reflection and interchange of } \\
\text { experiences; } \\
\text { - changes in the organization of } \\
\text { the existing support of the } \\
\text { school - focused on teachers } \\
\text { as well as students. } \\
\text { Sustainability with institutional } \\
\text { support. Design and } \\
\text { development of a school } \\
\text { inclusive action plan. }\end{array}$ & $\begin{array}{l}\text { Empowerment and autonomy: } \\
\text { they felt able to make decisions } \\
\text { about: } \\
\text { - changes in individual } \\
\text { practices. } \\
\text { - changes in the organization at } \\
\text { their phase of schooling. } \\
\text { Participation and adoption of } \\
\text { the approach: } \\
\text { - active participation in the } \\
\text { meetings and workshops; } \\
\text { - decisions about the process at } \\
\text { their phase of schooling. }\end{array}$ \\
\hline
\end{tabular}

It became apparent that transformations were directly linked to the level of involvement that school members have achieved to attend to diversity. Nevertheless, the sustainability of the changes, encouraged by the action research approach, would depend on the transformational leadership and support of those responsible for its development, the coordination team, and the representatives of the school management team. 


\section{CONDITIONS FOR DEVELOPING INCLUSIVE ACTION RESEARCH PROCESSES}

It seemed that inclusive action research processes need to be flexible and to adapt to the historical context, characteristics, tensions and dynamics of each school, in order to develop a process that could respond to the needs of the educational community and be meaningful for its members.

The approach needs to respond to the aims that each school has in relation to its stage in the development of inclusive education. It should concentrate on the analysis of facilitators and barriers to presence, learning and participation experienced by the members of the community. Special emphasis should be placed on responding to those groups of students vulnerable to marginalisation and exclusion.

It became apparent that reflection should be promoted by presenting school members with evidence related to the situation of the school, and with appropriate materials which could engage participants in the analysis of culturally-relevant topics.

The action research process should, we argue, focus on three levels: individuals, co-researcher teams and the educational community. This threelevel approach appears to have the capacity to adapt to the characteristics of schools and, at the same time, minimise their tensions.

At an individual level, the process should have the aim of fostering the staff's professional development, whereas the transformation of cultures and policies seem to be possible by promoting reflection at community level. In order to guarantee autonomy and sustainability, it should be recommended that a co-researcher team take charge of the coordination of the inclusive action research process. In addition, it also seems necessary to explore the possibilities of school representatives and professionals who could implement the approach in close relationship with external researchers.

\section{IMPLICATIONS FOR THE CHILEAN CONTEXT}

In the context already described, the inclusive action research model presented in this study, as well as other action research approaches, could strengthen the professionalism of staff and the structures for communication and decision making in schools, by focusing on three differentlevels: individual, coordination bodies, such as TPUs (technical pedagogical unit), and the educational community. 
We believe that a transition from the concept of the individual model of students' differences towards an organizational perspective could be achieved by the promotion of reflective processes. Through reflection on facilitators and barriers to presence, learning and participation, schools would be able to create space for continuing professional development and to re-organize their resources in order to respond to the learning needs of their members. The implementation of three-level collaborative action research processes within school-based programmes could contribute to the evolution of schools as learning communities.

By providing schools with incentives and conditions to carry out educational innovations based on collaborative action research processes to improve the learning and participation of all the students, we believe that the country could count on resourceful reflective schools and reflective teachers contributing to transformations towards an inclusive education system.

\section{Resources of the education system to support school-based programmes for improvement}

In Chile schools are offered a number of programmes and initiatives to respond to the characteristics and the educational demands of their populations. Despite this, these strategies are segregated programmes addressed to specific groups of students, such as disabled students or ethnic populations. Although most of the programmes have the aim of strengthening school pedagogical management and professional development, by concentrating on a particular group of students, others remain excluded. This situation is not coherent with the complex reality of schools' daily life.

Given the experience gathered during this research, we consider there should be an integration of the parallel programmes that are offered to schools. In the last Commission, consisting of relevant actors in education of the country, it was suggested that attention to diversity should be a principle to guide the articulation policies and the actions of the departments and sectors of the education system, towards interdisciplinary actions, with the purpose of establishing a more coherent and adequate educational response for all (MINEDUC, 2004b). Furthermore, those efforts should be concentrated on developing guidance and flexible resource materials to support schools in the adaptation of the curriculum and the pedagogical methodologies to the learning demands of their students.

The General Law of Education proposals in Chile recognise the need to strengthen the capacities of the regional departments of education to follow 
up and support schools to improve pedagogical processes. Within this line, the educational law proposes the creation of a national institution for supervision (Superintendencia de Educación). These bodies, we believe, should work as facilitators for schools' and teachers' reflective processes, in order to improve the quality of the educational experiences of their learners. In this way, supervisors would have a better understanding of the quality of education in the schools in the region, and those aspects that need attention.

In addition, the new law of education proposes a reform of the system of national assessment tests to measure the quality of education (SIMCE). The information offered in SIMCE should be adapted as a tool to improve pedagogical processes and diminish inequity. Collaborative analysis of the information within schools could be useful in order to expand educational plans that respond better to the needs of their students.

\section{NOTES}

1. We use the analogy of the south in two ways, the school is geographically situated in the south of Chile, and in addition, its characteristics could be generalised to other schools in underprivileged conditions.

2. We deliberately use the feminine genre as a generic voice throughout the text in order to highlight the role of women in education and research.

\section{BIBLIOGRAPHIC REFERENCES}

Ainscow, M., 1999

Ainscow, M., 2002

Ainscow, M. 2004
Understanding the development of inclusive schools. Falmer, London.

Using research to encourage the development of inclusive practices. In: P. Farrell and M. Ainscow, Making special education inclusive: from research to practice. London, David Fulton: 25-37.

Developing inclusive education systems: what are the levers for change? Paper presented at the Seminario Regional UNESCO "Salamanca 10 años después". Santiago, Chile. 
Ainscow, M., 2006

Ainscow, M., T. Booth \& A. Dyson, 2006

Ainscow, M., A. Howes, P. Farrell \& J. Frankham, 2003

Argyris, C., R. Putnam \& D. McLain Smith, 1985

Armstrong, F. and

M. Moore (eds.), 2004

Avalos, B., 2004

Baez, M., 1999

Bell, D., P. Caplan \&

W. J. Karim (eds.), 1993

Blanco, R., 2000
From special education to effective schools for all: a review of progress so far. In: L. Florian (ed.), The sage handbook of special education. London, Sage: 146-159.

Improving schools, developing inclusion.

Routledge, London.

Making sense of the development of inclusive practices. In: European Journal of Special Needs Education. 18(2): 227-242.

Action science: Concepts, methods and skills for research and intervention. Jossey-Bass, San Francisco.

Action research for inclusive education: Changing places, changing practices, changing minds. Routledge Falmer, London.

CPD policies and practices in the Latin American region. In: C. Day and J. Sachs, International handbook on the continuing professional development of teachers. Maidenhead, Open University Press: 119-145.

Developing inclusive education in Chile: private versus public systems. In: $\mathrm{H}$. Daniels and P. Garner, Inclusive education. World yearbook of education. London, Kogan Page: 148-159.

Gendered fields: Women, men and ethnography. Routledge

Inclusive education in Latin America. In: $\mathrm{H}$. Savolainen, H. Kokkala \& H. Alasuutari (eds.) Meeting special and diverse edu cational needs: Making inclusive education a reality. Helsinki, Ministry of Foreign Affairs of Finland: 40-51. 
Blanco, R., 2005

Booth, T. and M. Ainscow, Index for inclusion: Developing learning and 2002

Carr, W. and S. Kemmis, 1986

Corbett, J., 2001

DFES (1978)

Dyson, A., A. Howes \&

B. Roberts, 2002

Dyson, A. and

A. Millward, 2000

Echeita, G., 2006

Echeita, G. and

M. Sandoval, 2002

Elliott, J., 1991

Fals Borda, 0., 2001
Teachers and the development of inclusive schools. In: PRELAC Journal, 1: 174-177. Studies on Inclusive Education.

Becoming critical: Education, knowledge and action research. Falmer, London

Supporting inclusive education: A connective pedagogy. Routledge Falmer, London.

Report of the Committee of Enquiry into the education of handicapped children and young people. Her Majesty's Stationery Office, London.

A systematic review of the effectiveness of school-level actions for promoting participation by all students (EPPI-Centre Review, version 1.1). London, EPPI-Centre, Social Science Research Unit, Institute of Education. Available at http://eppi.ioe.ac.uk.

Schools and epecial needs: Issues of innovation and inclusion. Paul Chapman, London.

Educación para la inclusión o educación sin exclusiones. Narcea, Madrid.

Educación inclusiva o educación sin exclusiones. In: Revista de Educación 327:31-48.

Action research for educational change. Milton Keynes, Open University Press.

Participatory (action) research in social theory: origins and challenges. In: P. Reason and $\mathrm{H}$. Bradbury, Handbook of action research. London, Sage: 27-37. 
Finch, J., 1992

Gaventa, J. and

A. Cornwall, 2001

Gobierno de Chile (2002)

Gustavsen, B., 2001

Heron, J., 2001

Heron, J. and P. Reason, 2001

Karim, W. J., 1993

Kemmis, S., 2001
It's great to have someone to talk to: Ethics and politics of interviewing women. In: M. Hammersley, Social research: Philosophy, politics and practice. London, Sage: 166-179.

Power and knowledge. In: P. Reason and H. Bradbury, Handbook of action research. London, Sage: 70-80.

Proyectos deintegración escolar. Orientaciones 2002. MINEDUC. Santiago de Chile, Gobierno de Chile.

Theory and practice: the mediating discourse. In: P. Reason and H. Bradbury, Handbook of action research. London, Sage: 17-26.

Transpersonal co-operative inquiry. In: P. Reason and H. Bradbury, Handbook of action research. London, Sage: 333-339,

The practice of co-operative inquiry: Research 'with' rather than 'on' people. In: P. Reason and H. Bradbury, Handbook of action research. London, Sage: 179-188.

The 'nativised' self and the 'native'. In: D. Bell, P. Caplan \& W. J. Karim, Gendered fields: Women, men and ethnography. London, Routledge: 248-251.

Exploring the relevance of critical theory for action research: Emancipatory action research in the footsteps of Jürgen Habermas. In: P. Reason and H. Bradbury, Handbook of action research. London, Sage: 91-102. 
Kugelmass, J. W., 2001

Lather, P., 1986

Mcauliffe, D. and

A. Coleman, 1999

MINEDUC (2004a)

MINEDUC (2004b)

0’Hanlon, C., 2003

OCDE and MINEDUC (2004)

Park, P. , 2001

Pryor, J., 1998
Collaboration and compromise in creating and sustaining an inclusive school. In: International Journal of Inclusive Education. 5(1): 47-65.

Research as praxis. In: Harvard Educational Review. 56(3): 257-273.

Damned if we do and damned if we don't: Exposing ethical tensions in field research. In: Australian Social Work. 52(4): 25-31.

La Educación chilena en el cambio de siglo: Políticas, resultados y desafíos. Informe Nacional de Chile de la Oficina Internacional de Educación, UNESCO. Santiago de Chile, Ministerio de Educación de Chile.

Nueva perspectiva y visión de la educación especial. Informe de la Comisión de Expertos. Santiago de Chile, Ministerio de Educación de Chile.

Educational inclusion as action research: An interpretive discourse. Maidenhead, Open University Press.

Revisión de políticas nacionales de educación, Chile. París, Organización para la Cooperación y el Desarrollo Económicos.

Knowledge and participatory research. In: P. Reason and H. Bradbury, Handbook of action research, London, Sage: 81-90.

Action research in West African schools: Problems and prospects. In: International Journal of Educational Development. 18(3): 219-228. 
Reason, P., 1998

República de Chile (1994)

República de Chile (2007)

Rudolph, J. W.,

S. S. Taylor \&

E. G. Foldy, 2001

Schön, D., 1983

Schön, D., 1988

Schön, D., 1991

Torbert, W. R., 1991

Torbert, W. R., 2001

UNESCO (1994)
Three approaches to participative inquiry. In: N. K. Denzin and Y. S. Lincoln, Strategies of qualitative inquiry. London, Sage: 261-291.

Ley 19.284 sobre la Integración social plena de las personas con discapacidad, Gobierno de Chile.

Proyecto de la Ley General de Educación, Gobierno de Chile.

Collaborative off-line reflection: A way to develop skill in action science and action inquiry. In: P. Reason and H. Bradbury, Handbook of action research. London, Sage: 405-412.

The reflective practitioner: How professionals think in action. Ashgate, London.

Coaching reflective teaching. In: P. P. Grimmet and G. L. Erickson, Reflection in teacher education. London, Teachers College Press: 19-29.

The reflective turn: Case studies in and on educational practice. Teachers College Press, London.

The power of balance. Transforming self, society and scientific inquiry. Sage, Newbury Park.

The practice of action inquiry. In: P. Reason and $\mathrm{H}$. Bradbury, Handbook of action research.. London, Sage: 250-260.

The Salamanca Statement and framework for action on special needs education. World Conference On Special Needs Education, Salamanca, UNESCO. 
UNESCO (1999)

UNESCO (2001)

UNESCO (2004)

UNICEF and MINEDUC (2004)

Wadsworth, Y., 2001

Zeichner, K., 2001
Thematic study for EFA: Participation in education for all: The inclusion of students with disabilities. Santiago de Chile, Oficina Regional de Educación de la UNESCO para América Latina y el Caribe.

Overview of the 20 years of the Major Project of Education in Latin America and the Caribbean. Santiago de Chile, UNESCO Regional Office of Education for Latin America and the Caribbean.

Informe final del Seminario Regional "Salamanca, 10 años después". Santiago de Chile, Oficina Regional de Educación de UNESCO para América Latina y el Caribe

¿Quién dijo que no se puede?Escuelas efectivas en sectores de pobreza. Santiago de Chile, UNICEF.

The mirror, the magnifying glass, the compass and the map: facilitating participatory action research. In: P. Reason and H. Bradbury, Handbook of action research. London, Sage: 420-432.

Educational action research. In: P. Reason and H. Bradbury, Handbook of action research. London, Sage: 273-283. 